\title{
THE PROCESS OF GLOBALIZATION BEFORE AND AFTER THE 2008
} FINANCIAL CRISIS

\author{
Jugoslav Aničić1, Nataša Simić2, Vesna Petrović ${ }^{3}$, Dušan Aničićc \\ 1,2,3,4 University Union - Nikola Tesla, Faculty of Economics and Finance, Belgrade, Serbia, \\ ajugoslav@yahoo.com,nsimic68@gmail.com, al.petrovicpn@gmail.com
}

Original Scientific Paper 10.5937/jouproman8-28527

\begin{abstract}
Big financial crisis from 2008 has dramatically changed globalization process by reducing cross-border flow of capital, to a large degree. Crisis has shown numerous deficiencies and negative sides of this process, and there was a big displacement of world economy from developed western countries towards China and other countries in accelerated development. Symptoms of deglobalization, such as populism, economic protectionism and similar, haven't significantly changed the picture of constant integrative processes worldwide. Undoubtedly, in future, globalization will mostly be dependent on the three biggest and most significant economic, political and social entities in the world - USA, EU and China. Tail wind to an overall globalization process is given by Globalization 4.0, which is based on automatization by digital technologies with use in not only production processes, but in health care, education, transport, supply industry as well.
\end{abstract}

Key words: globalization, international relations, USA, EU, China

\section{Introduction}

Economic globalization is one of the most significant characteristics of modern world economy. All participants in the economy adapt to it: nations, regions, multinational corporations, as well as flows of money, loans and investments. It is institutionalized through different international economic organizations. Changes that appear during the beginning of $21^{\text {st }}$ century are primarily manifested through increased speed and absolute size of economic flows across national borders and by including more and more countries in global economy, because economic globalization was in the beginning, mainly limited to Western Europe, North America and Pacific Asia.
Globalization has changed the structure of world market in such a way that in a large number of economic activities only the biggest companies can realize profits on global market. Counties in the world are interconnected in a multidimensional network of economic, social and political relations. Individual national economies feel, more and more, both positive and negative effects of general movements in world economy and seek for the balance between economic independence and a degree of involvement into international economy. Global economy gains on importance when markets of certain countries are not large enough to enable forming of enterprises of optimal sizes.

During the last decade of $20^{\text {th }}$ century there was a significant change and displacement of world industry away from the old industrial economies - USA, Western Europe and Japan - towards Eastern Asia, Latin America and other countries in accelerated development. Although USA and other developed countries still possess most significant part of global wealth and industry, they are still in a certain decline, while some countries in development, especially China, have largely increased economic importance in international proportions. The biggest challenges of globalization in future period are consequences of global financial crisis from 2008 and a large reconsideration which appeared worldwide on justification, advantages and deficiencies of the previous globalization order. 


\section{The term and history of globalization}

Big financial crisis from 2008 broke the illusion of market which was seen as fetish and absolute, as well as of self-regulation of markets. Stiglic (2014) reminds that a man's economic activity is rooted into social and political milieu, and it is always medium for the achievement of social goals. He points out that "people should manage markets, not the other way round". Otherwise, there is a danger from market fundamentalism to man, society and natural environment. Such model resulted in general crisis which upsets modern society, both on global and national level. The process of decomposition of welfare state starts with the appearance of neoliberalism. European social model concept is particularly weakening, since it is seriously endangered by global financial crisis and rigorous savings and cutting of costs, which are, as measures in EU, imposed by Germany and IMF (Pikety, 2015).

According to Hopkins (2002), globalization is a process which transforms economic, political, social and cultural relations between countries, regions and whole continents. For Fridman (1999), globalization is an integration of markets, states-nations and technologies which enables individuals, corporations and statenations to stretch worldwide, further, faster, deeper and cheaper than ever before. For Waters (1995), globalization is a social process in which geographical limitations for social and cultural events tail away and people are becoming aware of that.

Dynamics of technological changes represents a dominant characteristic of globalization. It is followed by creation of aggressive development strategies, and thus adequate activities for their realization, which are based on comprehension of technological progress as a leader of transformation process, followed by forming of entirely new structures of societies and companies. Innovative organizations, which are based on constant learning, namely improvement of existing knowledge and acquiring new, which are in function of application and/or creation of new technologies, are being created (Stojanović, 2008).

Globalization brings a completely new qualitative dimension. The acceleration of this process is enhanced by exceptional technological progress and an unheard-of interdependence between countries and people. On the other hand, such dynamics has led to numerous abuses of globalization, misunderstandings and misinterpretations of both the term and a complete process. Globalization process has, in certain segments of modern society, diverged and broke away from noble goals of planetary progress and the reduction of differences in development of countries and nations.

The dominance of money, time and spatial dimensions on a global scale is the main goal of transnational corporations, because it is the best way to realize competitive advantages on global market, and through them profit, as the main imperative. Critics of globalization warn of the "high price" of globalization, which is reflected in increase of income inequality, high level of unemployment, pollution of the human environment, widespread of exploitation of natural resources and the consequences of unregulated financial flows on states' economies.

Globalization is actually "unification of human efforts and activities in the direction of accelerated integration of humanity, on the planetary level, induced by the movement of people, technologies, capital, information, ideas and cultural values between countries and nations, but in a way that both countries and nations do not control this process to the desired extent (Miletić, 2000). And in accordance with that, economic globalization is nothing else but the integration of the world which is taking place through trade, financial flows, exchange of technologies and information, as well as migration of population (Ouattar, 1997). 
Definitions of globalization hence differ depending on what is in their focus. Globalization is the name for the third phase of internationalization process in world's economy. In the first phase, from World War 2 to the end of 1960s, the main role was played by world trade, and the extent of internationalization was measured by the share in world's exports (OECD, 1992). According to James Stoner (2002), globalization phenomenon consists of three interrelated factors: a) proximity factor, b) organization's location factor and c) organization's open attitude factor.

Hopkins, as a definition, states the one according to which globalization is "a process which rearranges economic, political, social and cultural relations between countries, regions and entire continents, by concurrent widening, strengthening and acceleration of them" (Hopkins, 2002). For Friedman, globalization is "relentless integration of markets, countries-nations and technologies to a, so far, unseen extent, which enables individuals, corporations and countriesnations to stretch themselves worldwide in a faster, deeper and cheaper way than ever before... spreading capitalism's free market to every country in the world" (Friedman, 1999).

Dominant form of globalization marks historical transformation: in economy, on a way of acquiring income and existence; in politics, the loss of the extent of local control, and in culture, the loss of achievements of collectivity. Globalization arises as a political answer to the expansion of market power. It is in the area of knowledge (Mittelman, 2000). Ohmae (1995) thinks that, in modern economy without borders, market is the main initiator of globalization process.

According to Friedman (2005), historical overview of globalization is divided into three periods:

- Globalization 1.0 - from 1492 to 1800 , when the world is reduced from "big to medium" and when globalization was initiated by countries which were in the race for resources and colonies,

- Globalization 2.0 - from 1800 to 2000, when world was reduced from "medium to small" and when globalization's initiators were companies which were spreading towards new markets and new sources of workforce,

- Globalization 3.0 - from 2000till today, when world is reduced from "small to tiny" and where an individual is the main driving force of globalization.

Modern economic globalization could be observed through four waves (Crouch, 2018) which include: European imperialism, the reduction of tariffs under the guidance of USA and European integrations, neo-liberal deregulation and unique European market, collapse of communism and a growth of Far East.

Although, through history, there are a lot of factors that stimulated globalization and contributed to its progress, two of them imposed themselves as key, present and decisive in all historic phases, and those two are technological and political factor. Both of these initiators have to be observed in the function of economy, because only in economy, international trade their globalization effect is incarnated, and in many things their essence, too. Result of their operations is highly interconnected and interdependent world, world of open trade and flows of people, ideas, goods and capital, world in which that openness brings positive, but also negative consequences for individuals, community and natural and social environment of people (Dragaš, 2019).

At the beginning of the $21^{\text {st }}$ century, there were indications of economic crisis which will culminate in a major financial crisis from 2008 which will significantly affect global economic trends and GDP levels of certain countries. Economic growth of China and of other BRICS countries pointed out that world capital is no longer concentrated only in western countries - International Monetary Fund and World Bank, but there are alternative sources of capital and investments in other world regions. 
The latest global tendencies indicate that system of relying on dollar as world's currency and printing of money in order to cover up economic weaknesses, speculations on financial markets and create optimistic image of economic growth, is coming to an end. Western countries protect certain sectors (military and pharmaceutical industry, oil refining and others) for decades and enable them enormous profits. Positive reports are launched for the sake of preservation of stability of financial markets, stock exchanges and interest rates.

Western countries, primarily USA, became captives of quarterly reporting because results are often presented as better than they really are and because of obligations towards shareholders and a danger from collapses of stock exchanges. Illusion of stable economic growth is created through inflated stock exchanges. Growth of stockmarket indexes is many times higher than the real growth of GDP. It is a big problem to abandon acquired practice and for the countries to return to production and trade based on equality of all participants in that chain.

On the other hand, BRICS countries, primarily China, build their position in international relations on, so called, win-win principles, which means that they, much more than western countries, appreciate other countries in interrelationships. Real GDP of these countries is nominally underestimated because of lower prices than in western countries, while realistically it is already now on their level. As a consequence of real growth of GDP there is an accelerated development of infrastructure of these countries and approaching to western countries' development level.

Trade has stayed in the essence of globalization: it has surpassed exploitation as the most efficient way of acquisition and as a motivational power, too (Dragaš, 2019). Did the world after 2008 really "turned its back" to globalization, open trade and flow of people, communication and exchange of ideas and technological innovations? Is globalization in withdrawal or we live in a new form of it, the one which still holds the world interdependent and tightly connected by technological, economic, cultural and political relations?

\section{The impact of global financial crisis on globalization process}

What did global economy learn from 2008 crisis and which models now dominate global business scene, as a way to keep globality "on healthy feet"? What is the effect of new states' policies worldwide which advocate the closing of national markets' doors as means to save national economies and restore workplaces lost during globalization?

Financial crisis from 2008 shocked and intimidated capital worldwide, which was, until that moment, ready and willingly crossed national borders. Some noneconomic limitations, new political trends in direction opposite to integrations appeared, followed by crisis of international and supranational institutions. Political movements and leaders which advocate deglobalization, return to national frameworks and withdrawal from international agreements and integrations.

There is no doubt that the recession from 2008 fundamentally changed the picture of globalization, which ruled until then. Consequences are such that few people expect that international economic and political ambience will get back to level from period before 2008, and many people claim that such thing wouldn't be good. For example, cross-border flow of capital recorded in 2016, was at the level of only one third of the record level in the last precrisis year of 2007. The volume of capital that crossed national borders in 2016 was 4,3 trillion US\$, and the highest historical level was in 2007 and it amounted to 12,4 trillion US\$. It means that the recession decreased the international movement of capital three times during only one decade (UNCTAD, 2018). 
Table 1: Movements of some important macroeconomic indicators (2009 vs. 2018)

\begin{tabular}{|l|c|c|}
\hline & Before / During crisis & Decade after crisis \\
\hline Growth of GDP & $-1,8(2009)$ & $3,1(2018)$ \\
\hline Import of goods & 13,8 trillion US\$ (2009) & 17,7 trillion US\$ (2017) \\
\hline Export of goods & 3,59 trillion US\$ (2009) & 5,3 trillion US\$ (2017) \\
\hline Foreign Direct Investments & 1,98 trillion US\$ (2007) & 1,43 trillion US\$ (2017) \\
\hline Cross-border flow of capital & 12,4 trillion US\$ (2007) & 4,3 trillion US\$ (2016) \\
\hline Tourist trips (departures) & 897 million US\$ (2009) & 1.322 million US\$ (2017) \\
\hline
\end{tabular}

Source: World Investment Report, UNCTAD (2018)

Certain economists notice that an increase of FDI shows one unhealthy trend, corporations and investors are looking for lower fees and taxes, while countries compete in order to attract them by increasingly meeting their demands, sometimes even beyond the rules of a liberal, open market.

The fourth industrial revolution changes radically previous relations in the sphere of labor, migrations, social and economic policy at the state level. Faced with automation, digital platforms, workers are faced with competition that costs less on the market, is more productive and of better quality, and countries are facing the problem that the current mechanisms cannot protect their workers and their jobs. In the current technological revolution, workers from developed countries are not competing with workers from less developed economies with their lower wages. Both (those in the US and the ones in China) are competing robots and new technological systems, particularly those with lower education and poorer qualifications.

Industrial production and its labor force are in a great decline in terms of their share in the overall economy. The new economy, but also the new phase of globalization in which we participate, is based on knowledge and technological and process innovations. Technology stimulates global interconnectedness through digital corridors and in cyber-sphere, no longer through the physical movement of the labor force in search for jobs. The new way is faster, cheaper and more efficient, but it requires new knowledge and skills.

Under the influence of new technology, the new economy has already endangered thousands of jobs, a large number of companies and dislocated millions of workers. It dematerializes production by increasing the share of knowledge and reducing the volume of work in the newcreated value. Technology is also changing large infrastructure systems, such as health, transport, communications, energetics, which will require not only new models of work and management, but also completely new educational programs by which workers will acquire new skills.

Globalization 4.0 is not a negation or the opposite of the previous globalization because no country in the world (except for a few self-isolated ones) puts its resources on the fact that the process of strong international integration will inevitably move backwards. However, the appearance of a series of negative symptoms influences the question: whether these trends and processes can de-globalize the world or are they just a kind of reaction to its hyperphase, which peaked in 2008. 
In answer to this question, Colin Crouch tests the state of today's globalization with the help of "Rodrick's Trilemma", whose point is that it is impossible to preserve national sovereignty, democracy and hyperglobalization at the same time, but that it is possible to achieve at most two of these three elements (Rodrick, 2012). Crouch adapts globalization to today's conditions, in the sense that it can be more moderate, regulated by international agencies or regional associations, the OECD and the World Trade Organization.

The United States is the only politicaleconomic-security and technological entity that has shown that it is capable of inaugurating the processes of global integration, but also of endangering them to the extent that they are called into question. The current US policy is a reaction to the consequences of the "dark sides" of globalization, to which the US has not remained immune. The strengthening of American political and military unilateralism has brought long-term negative effects to the process of globalization. Also, the causes of the big crisis in 2008 were exclusively local (American), but the consequences were and remained global. The major disorders in international trade are not caused by objective economic or technological factors, but by protectionist measures of the US government (trade war with China, etc.).

After the World War 2, the USA was the biggest economic power with the most developed economy, it helped many other countries in the world and contributed to their renewal and development - Germany, Japan, Korea and others. Economic elites then applied an economic model of development that corresponded to their cultural condition, i. e. adapted to their own conditions, which gave very good results reflected in rapid and large economic growth.
However, in the 1980s, economic elites "betrayed" the United States by relocating industry to countries with cheap workforce. Financial capital took precedence over productive capital, the epicenter of economic developments became the maximization of profit, and all other goals became secondary. This was further intensified by the disintegration of the bipolar world and the realization that western-type capitalism is, by far, the most successful economic system.

The EU is in many ways a unique product of liberal aspirations for open societies, democracy, open markets and the firm connection of social and political systems and ideas. Its parliament is the only transnational parliament in the world, and the monetary union is the only creation of its kind. The attractive power of its value system is still unsurpassed and does not lose strength, which is best evidenced by the constant immigration to developed EU countries. Despite everything, the EU is more or less successfully coping with four simultaneous crises - economic, Ukrainian, migrant and Brexit.

China's economic development during the second half of the $20^{\text {th }}$ century was marked by a period of tight state control and protectionism, which later grew into a more open economic system, moving towards global integration. Commitment to global integration was confirmed by accession to the World Trade Organization in 2001. The gradual privatization of certain industries in China has transformed its poor economy into one of the largest in the world. By adopting policies that promote development in key sectors, alongside with export-based growth, China has become strongly integrated into the global economic system.

The peculiarities of the Chinese model of development differ greatly from the Washington consensus. Although it has accepted trade liberalization, the economic system in China is also characterized by (Philips, 2017): 


- keeping significant monetary
reserves in the state budget,
- state regulation of the exchange
rate,
- emphasis on state ownership and
-
sector.

China's path of economic development is also known as the East-Asian model of capitalism, because many Asian countries, before the pure form of capitalism, applied a mixture of free market capitalism and statecontrolled growth. This way, governments have had an influence on investing in certain sectors of the economy and encouraged growth depending on broader economic goals. An example of China's global influence is "The Belt and Road" project, which reaches a number of European countries, which are grouped in the "16 plus one" forum, eleven of which are EU members.

At the end of 1978, China began a policy of reforms and opening up. The program of economic reforms was called Socialism with Chinese characteristics and foresaw the transition towards a socialist market economy, the country's opening to the world and foreign trade, foreign investments and modern technology. The reformists aimed to accelerate the country's economic development through the introduction of market principles characteristic of capitalist economies and their combination with the socialist centrally planned economy (Janković, 2017).

China's policy abroad is strategically designed in the medium and long term. State-owned companies have direct support in large investment projects, and private ones partly direct and partly indirect support within state agreements. Although natural resources play an important role in foreign investments, their flows are shifting towards higher technological stages and developed industrial countries (Antevski, Filipović, 2014).The determinants of the sectoral and geographical distribution of Chinese investments abroad are confirmed by previous experiences of international capital movements.

From a geographical point of view, Chinese investments have a large dispersion, but they are mostly placed in developing countries. In these countries, China invests mainly in energetics and infrastructure projects. In developed countries, China considers the size of the market as a key factor and the goal of Chinese investors is to make a strategic takeover and positioning in those markets. China encourages its investors to invest in underdeveloped and developing countries by granting preferential status, while applying the criterion of reciprocity when it comes to developed countries. Trade is the first driver of investment capital, and investments in infrastructure projects additionally encourage trade growth (Filipović, Petrović, 2015).

The "Made in China 2025" strategy, in addition to upgrading existing industries and development of domestic market, envisages the development of ten priority sectors, from high technology, pharmaceutical industry, marine equipment to robotics and others. The strategic purchase of companies from these sectors leads to the fear of technology transfers to China, so from that point of view, the limitations set by the EU are understood, because short-term financial benefit would cause long-term weakening of EU countries on the world market. The advantages that China has at the domestic level, such as a high level of savings, a large and well-trained workforce, great opportunities for further urbanization, etc. are the pillars of preserving rapid economic development in the future.

\section{Current moment and the perspectives of globalization process}

The state of globalization in the three largest and most important economic, political and social entities when it comes to globalization - the United States, the EU and China - significantly affects the global state of this process. 
The coming years may bring a new wave of globalization, its stagnation or its withdrawal. Today's world is more connected than ever. However, some authors warn that the future of globalization remains uncertain and has the potential to go backwards in some aspects, as it was the case after the 2008 financial crisis. Whatever scenario awaits us, the biggest winners will be companies and countries that embrace globalization in its complexity, not those that succumb to the dichotomy between local and global vision of the future.

Klaus Schwab, founder and executive president of the World Economic Forum, says that we must always keep in mind that this is not a "zero-sum game" and that dichotomies like free trade or protectionism, technology or jobs, immigration or protection of citizens, growth or equality, are false: We can avoid these dichotomies by developing policies that will have "and" instead of "or", allowing the whole set of interests to be realized at the same time "(Schwab, K., 2018).

The biggest challenges of globalization are the consequences of the global financial crisis from 2008 and the great reexamination that has arisen around the world about the justification, advantages and disadvantages of the previous globalization element. Symptoms of deglobalization are populism, economic protectionism, withdrawal from international agreements and organizations, restrictions on migrants, etc. However, the influence of these factors has its maximum and cannot disturb the overall picture of constant integration processes around the world, especially in the countries on which the process of globalization depends the most, such as the USA, the EU and China.

According to Stiglitz (2018), international agreements concluded by the United States were designed to suit corporations, not the state and the welfare of its citizens and workers. He advocates the reconstruction of the international order based on rules into a system that will enable greater fairness, primarily in terms of distribution. He also believes that the original rules of globalization are "reversed", that globalization itself is not a problem, but a problematic way in which it is conducted. Because of all this, globalization has a future if "the rules of globalization are rewritten, in a way that is more fair to developing countries and with less dominance of corporate and financial interests."

The global picture shows that inequality is growing and that those who followed the American economic model usually fared worse than those countries that followed other models. The economic model that was promoted as the best possible, "liberalized" free market economy, did not serve large sections of the population well, even in the country that acted as the most liberalized and globalized, and most oriented to the free market - USA (Stiglitz, 2018).

This raises three questions: To what extent are these results a consequence of globalization? To what extent were they inevitable? And if it is because of globalization, to what extent does it happen because the rules of the game for globalization are poorly designed, and to what extent does it happen because some countries have shown little in managing the effects of globalization, considering those rules?

According to Stiglitz, globalization has played a central role, even though there have been other significant forces at play, such as technological change and changes in the structure of economy. Negative effects were not inevitable, they are the result of policies because globalization was poorly managed. The rules of globalization are partly to blame, for example, unfair to developing countries and have allowed free flows of capital that have had a destabilizing effect. 
However, even with such rules, developed countries should have prevented what happened, and do not allow so many developing countries to end up among the losers of globalization. So, a well-run globalization could have benefited everyone, and thus resulted in things, perhaps even for most citizens, being even worse.

Proponents of globalization have used simplified models that have not adequately addressed either benefits or costs. Because of that, it was overestimated, so the trust in it of the elites and the institutions, disappeared. It has also launched a race among countries to offer low tax rates to corporations and individuals. Global trade agreements were in the interest of corporations without sanctioning tax evasion. For example, corporate tax revenues fell from five percent of GDP in the 1950 s to two percent today (Stigliz, 2018).

\section{Conclusion}

The technological and political factors that must be observed in the function of the economy have contributed the most to the progress of the globalization process, because only in the economy globalization's effect is valorized, and in many respects its essence. The result of their actions is a highly interconnected and interdependent world, a world of open trade and flow of people, ideas, goods and capital, a world in which this openness brings positive but also negative consequences for individuals, community and natural and social environment. After the great financial crisis of 2008 , there is a great re-examination of the justifications, advantages and disadvantages of the globalization order. Symptoms of de-globalization such as populism, economic protectionism, etc. appear, but they have not yet changed the overall picture of ongoing integration processes around the world. The state of globalization in the three largest and most important economic, political and social entities when it comes to globalization USA, EU and China, as well as dilemmas and contradictions that arise in them in the post-crisis period decisively affect the stability and future of this process in all parts of the world.

\section{References}

Antevski, M., Filipović, S., (2014) Inostrane investicione aktivnosti kineskih kompanija, Medjunarodni problem 66 (3-4), p 231-248.

Filipović, S., Petrović, P., (2015) Pozicioniranje privrede u globalnom ekonomskom okruženju, Ekonomski institut, Beograd, p 122-123

Friedman, T.L, (1999): The Lexus and the Olive Tree,, p. 7-8

Friedman, ., T., (2005) „It“"s a Flat World, After all“, New York Times

Dragaš, O., (2019) Dva lica globalizacije - istina i obmane, Albion Books, Belgrade

Crouch, C., (2018) The Globalization Backlash

Hopkins, A. G.(2002) : The History of Globalization — and the Globalization of Histoły, A.G. Hopkins (ed.) Globalization in World History, (Pimlico,Sydney), pp. 16.

Janković, A., (2017) Chinas economic development : connectivity, Shinese Way, Silk Road Connectivity Research Center, Belgrade, p 40-41.

Mittelman, J. H.(2000) : "The Globalization Syndrome: Transformations and Resistance", Princeton: Princeton University Press, p. 6.

Miletić, D.S. (2000) „Proces globalizacije i problemi korupcije savremenog sveta", Zbornik radova na temu Sistem i korupcija, Centar za ekonomska istraživanja Instituta društvenih nauka, Beograd, p.p. 198.

Ohmae, K. (1995): „Putting Global Logic First”, Harvard Business Review, Journal, pp. 119.

Schwab, K., (2018) Globalization 4,0 - What does it mean? World Economic Forum

Rodrik, D., (2012) The Globalization Paradox: Democracy and the Future of the World Economy

Stiglic, J., E., (2018) Globalization and its Discontents Revisited: Anti Globalization in the Era of Trump

Stiglitc, J., E., (2014) Slobodan pad, Akademska knjiga, Novi Sad

Piketi, T., (2015) Kapital u 21. veku, Akademska knjiga, Novi Sad 
(JPMNT) Journal of Process Management - New Technologies, International

Vol. 8, No 4, 2020.

Philips, N., (2017) Global political economy

Stojanović, V.(2008); Tehnološki menadžment, APEIRON, Banja Luka, str. 233.

Waters, M.(1995) : Globalization, London-New York, itd: Routledge, Weiss., p. 3.
World Investment Report, UNCTAD (2018)

Ouattar, A.D.(1997): „The Challenges of Globalization for Africa", South Africa Economic Summit, World Economic Forum, Harrare, May 21, pp.2. 